\title{
Options for the Spatial Development of Russia in the Context of Interregional Interactions
}

\author{
A. V. Kotov* \\ Institute of Europe, Russian Academy of Sciences, Moscow, Russia \\ *e-mail: alexandr-kotov@yandex.ru \\ Received November 27, 2020; revised December 7, 2020; accepted December 15, 2020
}

\begin{abstract}
The article develops an approach to building a model of interregional interactions based on regionalization of national input-output tables. Options for the spatial structure of gross output depending on the forecast of investments in fixed assets are presented. Five main options for the prospective spatial organization of economic development are proposed. The advantages of the scenario of locally diversified growth, which is more acceptable from the point of view of territorial justice but requiring active state regulation of spatial development, are shown.
\end{abstract}

Keywords: spatial development, interregional interactions, matrix of interactions, shift-share analysis, scenario, investment, forecast

DOI: $10.1134 /$ S1075700721030072

Spatial economic policy options. General approaches to the development of scenario conditions for a general economic forecast are widely covered in the literature [1]. An example of the development of options for spatial development are forecasts of the socioeconomic development of the Russian Federation until 2030 and 2035 in the regional context, made at the Institute of Economic Forecasting of the Russian Academy of Sciences (IEF RAS) [2-4]; the results of using optimization interregional intersectoral models (OIIM) at the Institute of Economics and Industrial Engineering Siberian Branch RAS (IEIE SB RAS) may be seen in [5]. Interest in the regional aspect of forecasting is especially evident during economic crises. A detailed substantiation of the regional development scenarios was carried out in the framework of the analysis of the spatial consequences of the 2008-2009 global crisis by teams from SOPS, IEIE SB RAS, Economic Research Institute Far Eastern Branch RAS (ERI FEB RAS) RAS [6]. Abroad, the experience of scenario modeling of spatial development is in great demand, as shown by developments under the patronage of the European Commission with a horizon until $2030^{1}$ and $2050^{2}$. Separate effects of interregional interactions were

\footnotetext{
${ }^{1}$ Spatial Scenarios and Orientations in relation to the ESDP and Cohesion Policy. Final Report for ESPON project 3.2. ESPON. 2006. p. 46 url: https://www.espon.eu/sites/default/files/ attachments/fr-3.2_final-report_vol1.pdf.

2 Territorial Scenarios for Europe. Working Paper Annex to the ESPON Policy Brief "Territorial Scenarios for Europe towards 2050" // ESPON, 2015, 32p. URL: https://www.espon.eu/sites/ default/files/attachments/Working_Paper_2015-09-08_0.pdf.
}

studied in [7, 8], but in general they relate to the issues of constructing "isolated" regional forecasts.

Based on the well-known ideas about the horizontal relationships of economic macroregions of Russia [9], it is possible to form five main options for the prospective spatial organization of economic development:

-Inertial.

-Competitive.

-Locally diversified.

-Intensive development of Siberia and the Far East (Siberian doctrine).

-Active structural changes in the economy of old industrial federal districts (USV: Ural, Siberia, and Volga regions).

This description of the options refers to the period up to 2024 in accordance with the baseline forecast of the Ministry of Economic Development of Russia ${ }^{3}$.

Inertial. This scenario corresponds to the inertial version of the implementation of the Spatial Development Strategy of Russia ${ }^{4}$, which assumes the preservation of the current trends in the development of the settlement system and the economy. At the same time,

\footnotetext{
${ }^{3}$ Forecast of the socioeconomic development of the Russian Federation for 2021 and for the planning period of 2022 and 2023 // Ministry of Economic Development of Russia, 2020 URL: https://www.economy.gov.ru/material/directions/makroec/ prognozy_socialno_ekonomicheskogo_razvitiya/prognoz_socialogo_ekrazvitiya/prognoz_socialogo_ekonomicnahes_20_html.

${ }^{4}$ Order of the Government of Russia No. 207-r dated 13.02.2019.
} 
the tools of state regulation of spatial development are not actively used.

Competitive. This scenario assumes active economic development of the largest agglomerations and resource regions. In this scenario, the concentration of the population and economic activity in the hierarchical order of settlements will continue, with the "washing out" of human capital from small towns and rural areas. With regard to transport connectivity, first of all, the problems of development of road and rail corridors between the largest agglomerations will be addressed.

Locally diversified. This scenario provides for significant government regulation of spatial development aimed at a more even distribution of economic growth across the country. In this scenario, "counter-magnets" for employment are created in the regions and cities of the country, which slow down the process of excessive and uncontrollable concentration of the population.

Intensive development of Siberia and the Far East. This option meets the modern conditions of the "Siberian doctrine" [10], according to which the economy of Siberia should grow faster than the national economy as a whole, to ensure sustainable rates of economic development. This scenario simulates the active implementation of the "eastern vector" of the national economic policy, a significant redistribution of investment flows to the Siberian and Far Eastern regions. Priority is given to the development of Siberian and Far Eastern regions, the disclosure of the resource potential of the TransUrals at a new level with the obligatory science-intensive support of investment projects.

Structural changes in the economy of old industrial federal districts. This option provides for the redistribution of investments in fixed assets of the main industrial federal districts (Ural, Siberia, Volga regions), which have retained their industrial and human potential. The interrelated development of interregional projects of these three federal districts is considered as the main source of economic growth for the entire country and the impetus for other interregional interactions.

Regionalization of national input-output tables as a method of forming a model of interregional interactions. The first step towards a variant modeling of interregional interactions is to develop a matrix of interregional interactions based on the data of the national input-output table. The calculations are based on the original input-output table (IOT) for 2016 with a dimension of $98 * 98$ types of economic activities (TEAs) ${ }^{5}$. The problems of regionalization of the IOT are solved in research by various analytical methods [11-14]. In this case, the industry localization coefficients are calculated based on EMISS data ${ }^{6}$ according

\footnotetext{
5 Basic input-output tables for 2016 URL: https://rosstat.gov.ru/ storage/mediabank/baz-tzv-2016.xlsx.

${ }^{6}$ EMISS URL: fedstat.ru.
}

to the indicators of the average number of employees in the full range of organizations and on the shipment of their own goods produced, works and services performed by them in 2016 in the context of 185 TEAs. In the future, calculations are synchronized according to the 83 consolidated TEAs.

Regionalization of the initial IOT for each of the federal districts (FD) occurs according to the following algorithm. First, the foreign economic activity interaction matrices are calculated for each federal district. The strength of interactions between two industries in the FD is taken equal to the product of their localization coefficients. The more the two industries are localized in the FD, the greater their mutual influence is expected. The symmetric matrices of location coefficients for the FD are summed up to obtain the resulting matrix. At the next step, a structural-share analysis is carried out: the matrix of localization coefficients of each FD is divided by the resulting one. The values of structural coefficients by TEA are calculated for each FD by the formula:

$$
\frac{L_{i F O} * L_{j F O}}{\sum_{r=1}^{n} L_{i F O} * L_{j F O}} * z_{i j},
$$

where $L_{i F O}, L_{j F O}$ are the coefficients of localization of industries (types of economic activity) as producers $(i)$ and consumers $(j)$ in each federal district; $Z_{i j}$ are the technological coefficients of the enlarged IOT for the 83 TEAs.

Interregional economic interactions for each of the 83 enlarged TEAs are defined as the results of solving the same number of closed (or open) transport problems between all eight federal districts of Russia as suppliers and consumers of products. The general formulation of the transport problem for these purposes consists in determining a quasi-optimal distribution plan for some homogeneous products and goods from $m$ points of departure or production (FD) $F_{1 m}, F_{2 m} \ldots F_{8 m}$ in $n$ destinations $F_{1 n}, F_{2 n \ldots} F_{8 n}$. As a criterion of optimality, the minimum cost of transportation of all "cargo" is taken, usually directly proportional to the distance between points ${ }^{7}$. For this, a matrix of actual transport distances between the centers of the subjects of the Russian Federation by road is used ${ }^{8}$. The sum of the results for determining the quasi-optimal distribution of flows from $q$ individual sectoral tasks is presented as a general summary matrix of economic interactions in the FD.

\footnotetext{
${ }^{7}$ Development of methodology and techniques and verification of models for predicting indicators of socioeconomic development of the constituent entities of the Russian Federation, taking into account interregional interaction (final) // Report on R\&D. Head, Dr. Sci. (Phys.-Math), Prof. S.A. Ayvazyan, Moscow: TSEMI, 2005, p. 35.

${ }^{8}$ In the case of constituent entities of the Russian Federation without a road connection, the geographic distance was calculated.
} 
Table 1. Interregional Interaction Matrix (in the context of federal districts), 2016, trillion rub.

\begin{tabular}{l|c|c|c|c|c|c|c|c|c|c}
\hline \multicolumn{1}{c|}{ FD } & CFD & NWFD & SFD & NCFD & VFD & UFD & SibFD & FEFD & $\begin{array}{c}\text { Final demand } \\
\text { vector }\end{array}$ \\
\hline CFD & 37.5 & 1.00 & 0.85 & 0.19 & 1.54 & 1.93 & 0.77 & 0.41 & $13.54 * *$ & 57.73 \\
NWFD & 0.72 & 3.46 & 0.14 & 0.02 & 0.21 & 0.29 & 0.07 & 0.04 & 15.69 & 20.64 \\
SFD & 0.79 & 0.13 & 2.20 & 0.07 & 0.19 & 0.25 & 0.10 & 0.05 & 9.06 & 12.84 \\
NCFD & 0.26 & 0.01 & 0.02 & 0.57 & 0.02 & 0.02 & 0.01 & 0.00 & 3.81 & 4.72 \\
VFD & 1.13 & 0.17 & 0.17 & 0.03 & 6.40 & 0.39 & 0.16 & 0.06 & 19.46 & 27.97 \\
UFD & 1.27 & 0.19 & 0.17 & 0.05 & 0.39 & 4.94 & 0.34 & 0.11 & 18.79 & 26.25 \\
SibFD & 0.43 & 0.10 & 0.11 & 0.01 & 0.16 & 0.21 & 2.68 & 0.07 & 14.45 & 18.22 \\
FEFD & 0.21 & 0.11 & 0.07 & 0.01 & 0.07 & 0.11 & 0.03 & 0.50 & 10.12 & 11.23 \\
\hline
\end{tabular}

* The values of gross output in the context of federal districts were calculated in proportion to the volume of their GRP. For example, the high value of gross output in the Central Federal District and the low value of their final demand, in our opinion, reflects the effects of "pulling" of economic resources from other federal districts, administrative rent, and the practice of registering major companies in the Central Federal District.

Source: Author's calculations.

Using data on the gross regional product by federal districts, it is possible to represent the configuration of interregional economic interactions (Table 1) like Leont'ev's model, not in an intersectoral, but in an interregional, form, in the form of a static model of the interregional balance of product exchange ${ }^{9}$.

Substantiation of the regional distribution of the growth of investments in fixed assets in the options for spatial development. In accordance with the widespread foreign experience of building multiregional models-the Belgian HERMREG [16], the Dutch REGINA [17], the South Korean model for forecasting the regional economy [18]-the decomposition of the investment growth rate into three components is used as a basic technique in shift-share analysis:

$$
\Delta I_{r}=N S_{r}+I M_{r}+R S_{r},
$$

where $\Delta I_{r}$ is the investment growth rate in the forecast period; $N S_{r}$ (national shift), the national component of growth; $I M_{r}$ (industrial mix), the industry component of growth; and $R S_{r}$ (regional share), the regional component of growth in $r$ th region (entity of the Russian Federation) [19].

The national component of the growth rate of investments in fixed assets of the region $(N S)$ reflects the influence of general economic dynamics in the country as a whole. Industry component (IM) shows the impact that has on the growth of investment in fixed assets in the region, the dynamics of growth of a particular sector of the country's economy. In turn, the regional component of growth $(R S)$ demonstrates the influence of regional factors on the growth of investments in fixed assets in the region and shows the

\footnotetext{
${ }^{9}$ The problem of constructing a matrix of interregional interactions on the basis of a static MOB model using data on railway traffic was solved in [15].
}

degree of intensity of the development of one or another type of economic activity in the region.

For scenario calculations for spatial development options, the sum of the sectoral and regional components is important $D I F F=I M+R S$. It characterizes the differentiation of the distribution of investments in the regional context, while regions, as a rule, cannot influence the value of $N S$. Index DIFF thus acts as a differentiated addition to the national component. A similar methodological technique, for example, representing the value of predicted economic growth in a region as the sum of the national and territorially differentiated components, is used in the MASST family of models ${ }^{10}$ [20]. The DIFF value determines the strengthening of investment activity in the region and, as a result, more intensive interregional economic interactions along the existing production chains.

The volume of investments in fixed assets in the forecast period $I_{r}$ in the region $r$ is calculated as follows:

$$
\begin{gathered}
I_{r}=I_{r}^{\text {nat }}+I_{r}^{\text {diff }}, \\
I_{r}^{n a t}=N S_{r} * t_{r_{-} 2014-2018,}^{I} \\
I_{r}^{\text {diff }}=D I F F_{r} * t_{r_{-} 2014-2018}^{I}+\left(\frac{\sum_{j=1}^{n} \operatorname{Reg}_{\text {indicators }}}{n}-1\right),
\end{gathered}
$$

where $I_{r}^{\text {nat }}$ is the volume of investments in fixed assets in the forecast period in the region $r$ due to countrywide economic dynamics; $I_{r}^{\text {diff }}$ is the volume of investments in fixed assets in the forecast period in the region $r$ due to the specifics of regional development conditions; $N S_{r}$ is the volume of investments in fixed

\footnotetext{
${ }^{10}$ MASST-MAcroeconomic, Sectoral, Social, Territorial model.
} 
assets, due to the nationwide economic dynamics, in the retrospective period for the region $r ; D I F F_{r}$ is the volume of investments in fixed assets, due to regional conditions of development, in the retrospective period for the region $r ; t_{r_{-} 2014-2018}^{I}$ is the growth rate of investments in fixed assets in the retrospective period 20142018 in the region $r ; \operatorname{Reg}_{\text {indicators }}$ are the regional indicators of socioeconomic development.

Parameter $D I F F_{r}$ econometric regression is associated with indicators of regional development, the dynamics of which indicate an increase or decrease in investment activity in the region [21].

In the course of studying several dozen indicators, the following model was prepared:

$$
D I F F=f(\text { Reg_indicators }),
$$

where the following indicators are used as regional indicators, normalized to the average Russian level: $S \_S R$ is the funds of enterprises themselves (million rubles); $I F B$ is the investments in fixed assets from the federal budget (million rubles); $M F B$ is the multiplier of investments in fixed assets from the federal budget; $V_{-} O F$ is the commissioning of fixed assets (million rubles); $E E$ is the amount of electricity consumed in the region (million $\mathrm{kW} \mathrm{h}$.); $I_{-} M O D$ is the share of the total investment in fixed assets aimed at modernizing production; $S \_J$ is the volume of housing construction (million sq. $\mathrm{m}$ ); $V K_{-} Y L$ is the amount of deposits of legal entities in the accounts of commercial banks (million rubles); $D_{-} F L$ is the debts of individuals to commercial banks (million rubles); $T E$ is the export of products of the fuel and energy complex (fuel and energy resources) (million dollars); $\mathrm{CH}_{-} I$ is the import of chemical products (million dollars) (Table 2$)^{11}$.

Assessment of interactions based on the model of interregional product exchange. When forecasting the size of final demand by federal districts, its structure is taken in proportion to the structure of the projected gross regional product. The forecast GRP of the federal districts is determined by the existing regression dependences on investments in fixed assets for each district according to the data of 2014-2018 using the calculated forecast investment indicators. When calculating the total forecast growth of investments in fixed assets, the forecast of the Ministry of Economic Development of Russia until 2024 was used. According to that, the growth rate of investments in fixed assets was taken equal to 5.5-6.5\%, and a GDP growth rate of $3-3.5 \%$ per year. In accordance with these parameters and the described methodological approach, options for the structure of the distribution

\footnotetext{
${ }^{11}$ In order to perform averaging, as well as to include them in the model, regional indicators were normalized to the corresponding average Russian value. As a result, an array of values of regional indicators for all regions of the Russian Federation was obtained as deviations of the selected indicators from the average Russian level, taken as 1.0 for certain characteristics of socioeconomic development.
}

Table 2. Relationship between the DIFF parameter and indicators of regional economic development in 2014-2018*

\begin{tabular}{|c|c|c|c|c|}
\hline Index & Coefficient & Stat. error & $t$-statistics & $P$-value \\
\hline Const & -12.800 & 4.000 & -3.21 & 0.0020 \\
\hline$S \_S R$ & 8.929 & 3.112 & 2.87 & 0.0054 \\
\hline$I F B$ & 1.775 & 0.695 & 2.55 & 0.0128 \\
\hline$M F B$ & 5.418 & 0.670 & 8.09 & $<0.0001$ \\
\hline$V_{-} O F$ & -3.991 & 1.056 & -3.78 & 0.0003 \\
\hline$\overline{E E}$ & 1.487 & 0.750 & 1.98 & 0.0510 \\
\hline$I \_M O D$ & -2.192 & 1.723 & -1.27 & 0.2073 \\
\hline $\bar{S} J$ & 3.368 & 1.424 & 2.37 & 0.0206 \\
\hline$V K_{-} Y L$ & 2.185 & 0.624 & 3.50 & 0.0008 \\
\hline$D \_F L$ & -3.990 & 2.600 & -1.54 & 0.1291 \\
\hline$T_{-} E$ & 0.705 & 0.428 & 1.65 & 0.1039 \\
\hline$\overline{C H} \_I$ & -0.864 & 0.489 & -1.77 & 0.0815 \\
\hline
\end{tabular}

$* R^{2}=0.525$; adjusted $R^{2}$ is equal to 0.454 .

Source: Author's calculations.

of investments in fixed assets in the context of federal districts (Table 3) in 2018 prices were formed.

Thus, through a change in the interregional exchange of products, variants of the promising spatial structure of the economy are assessed, provided that the forecast indicators are achieved in Russia as a whole ${ }^{12}$.

Using the prepared model of interregional product exchange and option forecast indicators of final demand in the context of federal districts, the parameters of gross output are estimated for various spatial options.

$$
V_{k}=\left(E-C_{\text {interact }}\right)^{-1} * D k,
$$

where $V_{k}$ is the column vector of gross output in the context of federal districts according to the scenario of spatial development $k ; E$ is the unit matrix; $C_{\text {interact }}$ is the matrix of direct costs (based on the matrix of interregional interactions); $D k$ is the column vector of final demand in the context of federal districts according to the scenario of spatial development $k$.

Comparing the values of column vector $V$ from scenario to scenario leads to the conclusion about the spatial distribution of economic activity across the country.

Meaningful results. Although the calculations tested different hypotheses for the distribution of

\footnotetext{
${ }^{12}$ Forecast of the socioeconomic development of the Russian Federation for the period up to 2024 (Ministry of Economic Development of Russia)._URL: https://www.economy.gov.ru/ material/directions/makroec/prognozy_socialno_ekonomicheskogo_razvitiya/prognoz_socialno_ekonomicheskogo_razvitiya_rf_na_period_do_2024_goda_.html 30.20. The current forecast of the socioeconomic development of the Russian Federation for 2021 and for the planning period of 2022 and 2023 was presented on September 26, 2020. According to that, economic growth is expected, in our opinion, overly optimistic with the current policy-at least $3 \%$ by 2023 , which nearly coincides with the previous version of the forecast.
} 
Table 3. Options for the distribution of investments in fixed assets for $2024, \%$ of the total volume

\begin{tabular}{l|c|c|c|c|c|c}
\hline \multicolumn{1}{c|}{ FD } & Inertial & Competitive & Locally diversified & Siberia and Far East* & USV & 2018 (for reference) \\
\hline CFD & 30 & 35 & 27 & 13 & 13 & 28 \\
NWFD & 15 & 5 & 8 & 2 & 5 & 12 \\
SFD & 6.5 & 12 & 10 & 4.5 & 4 & 8 \\
NCFD & 3 & 4 & 4 & 8 & 20 & 3 \\
VFD & 12 & 19 & 16.5 & 9 & 36.5 & 13 \\
UFD & 17 & 13 & 23 & 28 & 3 & 9 \\
SibFD & 8 & 7 & 2 & 32 & 5.5 & 8 \\
FEFD & 9 & 5 & 9 & & \\
\hline
\end{tabular}

* In order to more clearly demonstrate the effects of spatial development and in conditions of a fairly conservative structure of investment distribution, for the options "Siberia and the Far East" and "Ural, Siberia, the Volga region", stronger prerequisites for the distribution of investments were used. In our opinion, in general, such a distribution of investments is quite possible after 2030 in the context of an active investment policy and a significant adjustment of the current economic course.

Source: Author's calculations.

Table 4. Gross output in macroregions of the Russian Federation in 2024 by options, trillion. rub.

\begin{tabular}{l|c|c|c|c|c}
\hline \multicolumn{1}{c|}{ FD } & Inertial growth & Competitive growth & Locally diversified growth & Siberia and the Far East & USV \\
\hline CFD & 64.6 & 61.3 & 51.7 & 45.8 \\
NWFD & 23.6 & 15.4 & 15.3 & 59.5 \\
SFD & 12.4 & 14.9 & 13.0 & 17.4 & 21.3 \\
NCFD & 4.3 & 7.3 & 5.1 & 4.3 & 13.1 \\
VFD & 23.7 & 37.6 & 42.7 & 4.7 \\
UFD & 27.8 & 23.1 & 26.6 & 18.6 & 51.1 \\
SibFD & 18.9 & 18.4 & 26.9 & 56.4 \\
FEFD & 14.2 & 7.7 & 14.7 & 44.5 & 10.4 \\
Total & 189.6 & 185.6 & 196.0 & 30.1 & 3.3 \\
\hline
\end{tabular}

Source: Author's calculations.

investments and the formation of the final territorial structure of the GRP, the spatial structure of gross output did not undergo significant changes. In the inertial and competitive scenarios, the undisputed leader remains the Central Federal District (Table 4).

Resource regions of the Trans-Urals and the Arctic in the inertial option remain a raw material base with a slight increase in the manufacturing industry (mainly in the southern part of Siberia) and autonomization of development [22]. Key implementation benefits of the locally diversified scenario are received by the regions of the Siberian, Ural, Far Eastern federal districts. In the scenario Siberia and the Far East, there is an investment maneuver from the Central, Northwestern, Volga, Ural federal districts to the Siberian and Far Eastern districts. In USV (Ural, Siberia, and Volga regions), the leaders are the Volga and Ural federal districts.

The scenario of locally diversified growth implies the return of the links of value chains to where they were formed, to Siberia, through the processing of natural resources and the development of a range of energy and water-intensive industries: both traditional (chemical, petrochemical industries) and new (for example, the microbiology industry) [23]. If the European part of the country and the largest metropolitan areas benefit in almost any scenario, then the decrease in investment activity in the eastern part of the country leads to deepening spatial imbalances.

The scenarios Siberia and the Far East and USV have good final indicators of gross output, but a sharp increase in production capital investments in these regions with the current small share of centralized investment is unlikely. In our opinion, this raises the problem of echeloning economic growth (based on existing opportunities and a gradual deepening of resource processing) and organizing a process for the accumulation of investment resources for targeted programs for modern development of the territories.

The real basis for the integration of the subjects of the Federation within the Siberian doctrine scenario can provide the available scientific potential. The main goal in this case should be to bring the centers of added value closer to the centers of production of knowledge and technologies: in the mineral resource 
complex; in Siberian oil, coal, timber and gas chemistry; in power electronics ${ }^{13}$; in the field of biotechnology and pharmaceuticals, electron beam technologies, etc. $[24,25]$.

For the Urals Federal District, the optimal scenario will provide for advanced import substitution, and the use of resources of the military-industrial complex for the production of high-tech products for civilian industries. Technological cooperation and the complementarity of the economies of the Ural regions open up additional opportunities for working in the domestic Russian market and its expansion. As the potential of other factors is realized (the formation of world-class scientific and educational centers, the creation of interregional innovative alliances, digital industrial platforms), the result of interactions may be the formation of new production and technological chains in the Volga region, the Urals and western Siberia. It is important for the Urals to develop a procedure for selecting such interregional projects that would change the structure of interactions as a whole ${ }^{14}$ and would be based on the technologies of the fifth or sixth technological orders (the military-industrial complex, the production of unmanned aerial vehicles, robotics, nanomaterials, the nuclear industry, new technology for the North and the Arctic) [26].

Conclusions. Calculations show that there is no single optimal variant of spatial and economic development. Based on the modeling results, the locally diversified scenario appears to be the closest to implementation (in terms of the objective possibility of rebalancing investments in fixed assets and indicators of gross output). But its implementation is associated with the need to change the current national economic policy.

The spatial development options laid down in the 2019 Spatial Development Strategy require adjustment in terms of both the initial assumptions and the analysis of the spatial consequences of the coronavirus epidemic. For the long-term development of the country, the main trends of territorial development should remain relevant with nearly any change in current and future economic events: the gradual economically justified involvement of productive forces in the east of the country using technologies of the fifth and, in the future, sixth technological modes. However, the intensity of this process can be different, and most importantly, the volumes of the irreducible "investment minimum" of the federal budget funds aimed at the development of specific regions and catalyzing private investment can be different.

\footnotetext{
${ }^{13}$ Power electronics is a field of technology related to the control of the flow of electricity by means of powerful electronic devices, which covers industry, mining, transport, communications.

${ }^{14}$ In the EU planning cycle for 2021-2027, for the first time, a special investment program is envisaged to support "interregional innovation investments" (Component 5 on interregional innovation investments) URL: https://www.interregeurope.eu/future/.
}

At present, the patterns of interregional interactions can be characterized as the ongoing exchange of the potential for balanced spatial development for the predominantly infrastructural arrangement of agglomerations and connections between them. In the short term, this is quite justified. But in the long term, it can lead to restrictions on economic growth in terms of creating conditions for the comprehensive spatial development of the country.

\section{FUNDING}

The article has been prepared in accordance with the State Assignment for Research of the RANEPA under the President of the Russian Federation.

\section{REFERENCES}

1. A. A. Shirov and M. S. Gusev, "Development of scenario conditions as a key stage of economic forecast preparation," Stud. Russ. Econ. Dev. 22, 11-19 (2011).

2. N. N. Mikheeva, "Assessment of scenarios for the spatial development of the Russian economy until 2030," Nauchn. Tr. Inst. Narodnokhoz. Prognozirovaniya Ross. Akad. Nauk 15, 405-423 (2017).

3. N. N. Mikheeva, "Long-term forecasts of regional development: Analysis of results and the problem of development," Stud. Russ. Econ. Dev. 29, 470-480 (2018).

4. Post-Crisis Economic Recovery and Main Directions of Forecasting the Socio-Economic Development of Russia for the Period up to 2035: Scientific Report, Ed. by A. A. Shirova (Nauka, Moscow, 2020) [in Russian].

5. V. I. Suslov and N. M. Ibragimov, "Development of economic and mathematical tools," in Fundamental Problems of Spatial Development of the Russian Federation: Interdisciplinary Synthesis (Media-Press, Moscow, 2013), pp. 570-576 [in Russian].

6. A. G. Granberg, N. N. Mikheeva, Yu. S. Ershov, V. V. Kuleshov, V. E. Seliverstov, V. I. Suslov, S. A. Suspitsyn, and P. A. Minakir, "The impact of the global crisis on the strategy of spatial socio-economic development of the Russian federation," Reg. Res. Russ. 1, 2 (2011).

7. E. V. Lukin, "Interregional interaction in the system of economic development of regions: Theoretical and practical approaches," Ekon. Territ., No. 5, 1-9 (2013).

8. A. V. Belousova, "Interregional interactions: Impact on the regional economy (Khabarovsk krai)," Prostranstvennaya Ekon., No. 4, 127-137 (2012).

9. Strategies for Russian Macroregions: Methodological Approaches, Priorities, and Ways of Implementation, Ed. by A. G. Granberg (Nauka, Moscow, 2004) [in Russian].

10. To the 80th Anniversary of the Birth of Aleksandr Grigor'evich Granberg: Scientist, Teacher, Man, Ed. by V. I. Suslov and S. A. Suspitsyn (IEOPP SO RAN, Novosibirsk, 2016) [in Russian].

11. J. Malte, A. T. Flegg, and T. Tohmo, "Testing and implementing a new approach to estimating interregional output multipliers using input-output data for South Korean regions,” Spatial Econ. Anal. 15 (2), 165-185 
(2020)

https://doi.org/10.1080/17421772.2020.1720918

12. T. Fujimoto, "Appropriate assumption on cross-hauling national input-output table regionalization," Spatial Econ. Anal. 14 (1), 106-128 (2019). https://doi.org/10.1080/17421772.2018.1506151

13. R. Boero, B. K. Edwards, and M. K. Rivera, "Regional input-output tables and trade flows: An integrated and interregional non-survey approach," Reg. Stud. 52 (2), 225-238 (2018).

https://doi.org/10.1080/00343404.2017.1286009

14. Yu. S. Ershov, "Regionalization of input-output tables," EKO, No. 6, 119-138 (2011).

15. A. A. Shirov, "Assessment of interregional economic interactions using statistics of freight railway transportation," Stud. Russ. Econ. Dev. 31, 153-161 (2020).

16. D. Hoorelbeke, O. Lohest, D. Bassilière, F. Bossier, I. Bracke, and F. Caruso, "HERMREG: A regionalisation model for Belgium," in EcoMod2007 (2007).

17. A Survey of Spatial Economic Planning Models in the Netherlands. Theory, Application and Evaluation, Ed. by F. Van Oort, M. Thissen, and L. van Wissen (Neth. Inst. Spatial Res., Den Haag, 2005).

18. L. Hyun-kyung and K. Hong-bae, "Weighted spatial dynamic shift-share model as a forecasting tool for a regional economy: The case of South Korea," Growth Change 51 (2), 734-748 (2020). https://doi.org/10.1111/grow.12377

19. H. W. Richardson, "The state of regional economics: A survey article,” Int. Reg. Sci. Rev. 3 (1), 1-48 (1978).

20. R. Capello, A. Caragliu, and U. Fratesi, "Modeling regional growth between competitiveness and austerity measures: The MASST3 model," Int. Reg. Sci. Rev. 40 (1), 38-74 (2017).

https://doi.org/10.1177/0160017614543850

21. I. V. Grishina, "Forecasting the inflow of investments in fixed assets of regions for the period up to 2024: Methods and results of developing a territorial section of the forecast for the development of Russia," Reg. Ekon., Yug Ross. 8 (1), 49-62 (2020).

22. V. A. Kryukov and Ya. V. Kryukov, "Interaction of the north and south of Siberia: Resting on the "Management" of multiplier effects," in The Power of Siberia Will Grow?! Collection of Reports of the International Scientific Forum "Education and Entrepreneurship in Siberia: Directions of Interaction and Development of Regions" (Novosib. Gos. Univ. Ekon. Upr., 2018), pp. 300-303.

23. Siberia and the Far East in the 21st century: Scenarios for the Future: Analytical Report, Ed. by V. S. Efimov (Sib. Fed. Univ., Krasnoyarsk, 2018) [in Russian].

24. From the Idea of Lomonosov to the Real Development of the Territories of the Urals, Siberia, and the Far East, Ed. by A. I. Tatarkin, V. V. Kuleshov, and P. A. Minakir (Ural. Otd. Ross. Akad. Nauk, Inst. Ekon., Yekaterinburg, 2009) [in Russian].

25. A. N. Klepach and N. N. Mikheeva, "Outstripping growth of the Siberian economy: Realities and opportunities in the megaproject 'Russian Ark'," EKO, No. 8, 66-86 (2020). https://doi.org/10.30680/ECO0131-7652-2020-8-66-86

26. Ya. P. Silin, "Strategic dominants of new industrialization in the space of the Ural macroregion in the 21st century," Nauchn. Tr. Vol'nogo Ekon. O-va. Ross. 209, 136-162 (2018). 